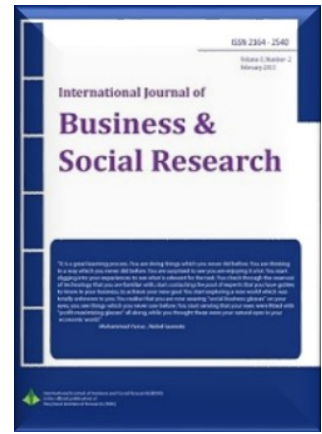

\title{
Religiosity, Job Status and Whistle-Blowing: Evidence from Micro-Finance Companies
}

\begin{abstract}
Albert Puni', Collins B. Agyemang ${ }^{2}$, Emmanuel S. Asamoah ${ }^{3}$
ABSTRACT

We investigate the effect of religiosity and job status on whistle-blowing among employees of micro finance companies in Ga-East district of Ghana. The intellectual dimension of religiosity informs and produces high sense of morality in an individual thus influencing whistle-blowing. Additionally, religion create the platform for building belief in certain rules and regulations as right or as wrong. Using quantitative approach for analyzing the effect between independent variables (job status and religiosity) on the dependent variable (whistle-blowing), we show that though religiosity and job status can influence whistle-blowing, however in this study, the magnitude is negligible and perhaps other variables in concert with religiosity and job status may influence whistle-blowing activities in an organization. We conclude that that whistleblowing generally in the Ghanaian setting is yet to receive high prominence due to the general belief of lack of protection for persons who come out to expose wrongdoings and the general fear of harassment, victimization and loss of job by the whistle-blower.
\end{abstract}

Keywords: Job status, micro-finance companies, religiosity, whistle-blowing.

Available Online: 20-03-2016.

This is an open access article under Creative Commons Attribution 4.0 License, 2016.

\subsection{INTRODUCTION}

Whistle-blowing has gained global attention and popularity over the last two decades with most cases centered on the disclosure of unethical or illegal behavior, of employers or officials at work by employees to a third party (Johnson, 2003). However within the past decade, the frequency of organizational wrongdoing across the world has assumed unprecedented proportions, evident from the constant media coverage of such incidents (Bowen, Call \& Rajgopal, 2010). Although some whistle-blowers receive praise for their actions, many others are subjected to victimization and sometime total rejection by their community (Dyck, Adair, \& Zingales, 2010). Whistle-blowing is made mostly by employees who are privileged to the organization's unethical behaviors. Example can be said of the Enron and WorldCom

\footnotetext{
${ }^{1}$ University of Professional Studies, Department of Business Administration, Accra, Ghana. E-mail: albert.puni@upsamail.edu.gh

2 University of Professional Studies, Department of Business Administration, Accra, Ghana. E-mail: collins.agyemang@upsamail.edu.gh

3 University of Professional Studies, Department of Business Administration, Accra, Ghana. E-mail: emmanuel.asamoah@upsamail.edu.gh
} 
debacles, when Sherron Watkins and Cynthia Copper respectively exposed the use of the creative accounting practices by their respective organizations in booking sales which lead to fictitious profits and the diversion of billions of dollars in debt of failed deals and projects.

It is believed that the risk of corruption is significantly heightened in environments where the reporting of wrongdoing is not supported or protected (OECD, 2012). Consequently, in 2006 the Ghanaian Parliament passed the Whistle-Blowers Act (Act 720) to encourage people to expose the unethical or corrupt practices of their employers or higher officials at the work place to the appropriate agencies without fear of victimization, abused, threat, or assault. Despite the positives of whistle-blowing, there is the perception that many Ghanaians see whistle-blowing as witch-hunting and are reluctant in exposing unprincipled acts that are likely to cause injury to the public by their employers or officials at work be it private or public sector organizations.

Also apart from the unwillingness to expose wrongdoing in Ghanaian organizations, generally, previous studies exploring whistle-blowing have concentrated on organizational and structural factors influencing whistle-blowing in the areas of professional status of whistleblowers, and organizational support for whistleblowing (Near \& Miceli, 1985; Dozier \& Miceli, 1985; Vadera, Vadera, \& Caza, 2009). There are however scanty researches dealing with how the belief system of an individual and the position the individual occupy on the organizational hierarchy affect whistle-blowing. Unfortunately too, many of the researches dealing with the latter have been concentrated in advance countries with very little literature from a developing country's perspective. Ghana being a religious country of Christians, Muslims and African Traditionalist, one may think that the morality doctrines espouse by these religious faiths will inspire individuals to blow the whistle of any wrongdoing in their organizations. In the light of the above the authors have explored the effect of religiosity and job status on whistle-blowing in Ghana.

Religiosity is the faith, belief, piousness, devotion, and holiness expected by an individual in a religious sect (Lewis, 1978). The intellectual dimension of religiosity informs and produces high sense of morality in an individual thus influencing whistle-blowing (Glock and Stark 1965). Additionally, religion create the platform for building belief in certain rules and regulations as right or as wrong. These rules are held in high esteem by the individual, creating a standard of morality in relation to how the individual response to ethical issues in the organization. The role theory in social psychology also consider how employees in the various hierarchical organizational structure behaves and take decision that affect others. The decision of exposing wrongdoing is often connected to the hierarchical level of the employee because of fear of victimization. Nevertheless, the debate of whether religiosity and job status positively or negatively affect whistle-blowing is inconclusive. Some are of the view that religiosity and job status positively affect whistle-blowing (Barnett et al, 1996; Near \& Miceli, 1985; Dozier \& Miceli, 1985; Vadera, Vadera, \& Caza, 2009; Gino \& Bazerman, 2009). Others also suggest that religiosity and job status have no association or negatively affect whistle-blowing (Goldman, 2001; Keenan, 2000). The inconclusiveness of previous findings of whether religiosity and job status affects whistle-blowing is problematic especially in an environment where people are extremely religious but whistle-blowing is seen as witch-hunting. Even though whistle-blowing can serve as an antidote to minimizing corruption in Ghana, the behavioral and structural factors influencing the decision to whistle-blowing in Ghana have not be investigated. Also individuals at various levels of organizational hierarchy take certain decisions and actions on how issues ought to be handled when it is in their power to do so. In exercising these powers, many tend to consider their position as well as how they view what constitutes wrongness or rightness. Thus, the main objective of this study is to investigate the effect of religiosity and job status on whistle-blowing among employees of micro finance companies in Ga-East district of Ghana.

\subsection{WHISTLE-BLOWING}

Although there are several different definitions of whistle-blowing (Barnett et al, 1996; Near \& Miceli, 1985; Miceli et al., 2008; Miceli and Near, 1988), the concept can best be explained as going public with organizational information that threatens the public interest. Boatright (2000) defined whistle-blowing as "the voluntary release of non-public information as a moral protest, by member or former member of 
an organization outside the normal channels of communication to an appropriate audience about the illegal and/or immoral conduct in the organization that is opposed in some significant way to the public interest (p. 109). Park et al (2008) added that whistle-blowing involves the reportage of wrongdoing by following official organizational communication channels. Whistle-blowing entails eight elements; the employee or former member of the organization, the organization or members of its management which/who is involved in the unethical or immoral act, the recipient or the appropriate agency which/who received the information, the nature of the immoral conduct, the document showing evidence of the unethical act, the disclosure of immoral conduct outside the normal channel either internal or external, the motive behind the whistle-blowing which must to voluntary, and the outcome which is to stop the act and protect the public interest or injury (Chiu, 2003, Boatright, 2000, Jubb,1999)

Furthermore, the choice of employees' whistle blowing activities can be internal or external. Internal whistle blowing encompasses the disclosure of wrongdoing to a supervisor within the organization whiles external whistle blowing is reporting unethical activities to an outside parties believed to have the power to correct it. It therefore presuppose that the motivation towards internal whistle blowing is dependent upon the existence of effective internal channels of complaint in the organizations. Contrary, the choice of external whistle blowing is dependent upon when the employee feel that the wrong doing will harm the public. Though whistle-blowing can be described as an honorable act geared towards exposing immoral or unethical act by organizations and its members, in reality not every whistle-blowers receives commendation from the employer. Usually many whistle-blowers experience exclusion, rejection, threat of revenge, demotion, and loss of employment (OECD, 2012, Lennane, 1996). Lennane (1996) is of the view that ninety percent of whistle-blowers lose their jobs or are demoted when they blow the whistle. Contrarily, there are few instance where whistle-blowers have received praise in terms of promotion and cash reward for their actions. Example can be said of the Abbey National case where the whistle blower received some cash reward and was promoted to a senior position in the organization and also where whistle-blowers were offered $\$ 52$ million for exposing medi-care insurance fraud by SmithKline Beecham (Ferrel et al, 2002, Lynn, 1998)

\subsection{BEHAVIORAL FACTORS INFLUENCING WHISTLE-BLOWING}

Many theorist in an attempt to investigate unethical behavior in the work place have often used the intention to disclosure as an operative variable because of the inability of exploring unethical behavior in the work place by observation (Victor et al., 1993, Chiu, 2003). Others also used situational, environmental, and contextual factors based on educational status, age, sex, religious background and cultural and societal value in explaining factors influencing whistle-blowing. For the purpose of this research the intrinsic, extrinsic and altruistic social dominance orientation theory has extensively been adopted.

Behaviorists have used the social dominance orientation theory for the purposes of explaining human behavior at various moments and thus the intention of an employee to blow the whistle because it has been suggested that behavioral intension is an ideal predictor of actual behavior and thus suitable in explaining factors influencing whistle-blowing (Ajzen, 1991). Consistently, Martin (2013) asserted that intrinsic social factors are internal motivation an employee or a person had to expose wrongdoing without the intention of reward for doing the right thing. Chiu (2003) has referred to the intrinsic factor as ethical judgment; the formation of behavioral intention toward a certain ethical or moral issue because it is an integral component of an individual's attitude toward the issue. Employees who appears to be fearless as to what can happen to them for exposing an illegality or wrongdoing were said to possess intrinsic social factors. Intrinsic or ethical judgment has been included in many models of ethical decisionmaking especially in situations where moral consideration is used in the ethical decision-making process (Hunt and Vitell, 1986; Jones, 1991; Rest, 1986; Trevino, 1986). Chang (1998) is of the view that people who highly evaluate the wrongness of an action and perceive the rejection of the action by others, are more likely to refute such action and also possible expose anyone found in act of that wrongness.

Extrinsic social factors are superficial aspect of the social dominance orientation theory; where whistle- 
blowing is mostly motivated or encouraged by an instituted reward system before the exposure of any illegality or wrongdoing in the organization (Martin 2013). Consistently, employees would expose an illegality only when they knew they would be hailed as heroes or be compensated with cash and/or promotion. Their intension to blow the whistle is self-focused and centered. Ajzen (1991) opines that whistle-blowers are motivated by the degree which suggest that the situation is favorable and secured. The altruistic social dominance factor is viewed as a combination of the intrinsic and extrinsic factors. Whistle-blowers who possessed such trait would blow the whistle seeking publicity, self-glory, and reward but also reinforce the need for attitudinal change and positive improvement on general behavior in an organization.

The social dominance orientation theory links one's level of religiosity and spirituality to whistle-blowing. An employee who possessed the intrinsic social factors described by Martin (2013) was adjudged more religious and mostly adhere to rules and regulations of the organization. No matter the sex, race, age, educational background of the individual, he or she is highly motivated to expose wrongdoings. A strong relationship with God and belief in the doctrines of their faith is greatly exhibited and exercised by such employees. The social dominance theory is based on the work of Allport and Ross (1967) who opines that the intrinsically motivated person uses his religion, whereas the extrinsically motivated person lives his religion. Role theory is a perspective in social psychology that considers the predictable ways in which individuals behave in an anticipated way based on their social position and other factors. It deals with set of rights, duties, norms and behaviors that an individual faces and fulfills in a particular position. Actions of individuals in an organization can be linked to this theory that causes them to behave in different ways due to the positions they hold. By virtue of this, employees in taking decisions consider their positions and would be careful not to take actions that will be deemed higher than the power they wield in the organization.

\subsection{HYPOTHESIS DEVELOPMENT}

The following section reviews empirical literature on the relationship between the independent variables, thus Religiosity and Job Status and the dependent variable, thus Whistle-Blowing in order to formulate hypothesis for the study

\subsection{RELIGIOSITY AND WHISTLE-BLOWING}

Othman and Hariri (2012) conceptualized that religiosity influences whistle-blowing intentions by other studies linking religiosity to human behaviors like drug abuse (Chu 2007; Kendler, et al., 2003; Stylianou, 2004). Ferm (1963) has earlier stated that individual described as religious are likely to clench on certain religious beliefs and also practice them on a daily bases. These shared religious beliefs can be branded as cooperative, affectionate, civil, truthful, preferring safety, harmony and stability. Religious individuals are therefore more law abiding and will blow the whistle whenever they are confronted with unethical behaviors in the workplace Rokeach (1969). Consistently, Keenan (2000) established that whistleblowing activities among managers are positively linked to their religious beliefs and will blow the whistle in less serious fraud. Reason being that religious values shape the behavior of the individual in any society and this is manifested in the different people across various cultures. Fernando and Jackson (2006) have suggested that individuals who are religious behave in accordance with the values inherent in those religion and will not countenance any unprincipled behaviors, hence the likelihood to blow the whistle when confronted with an unethical situations are very high. There are however scanty literatures on individuals who observe wrongdoing in the workplace but chose not to report to superiors or appropriate authorities. The scanty nature of literature may probably due to the persecution and sometime total denunciation by the community on whistle blowers (Dyck, Adair, \& Zingales, 2010). Based on the literature the authors' hypotheses that:

$H_{1}$ : There is positive significant effect between religiosity and whistle-blowing. 


\subsection{JOB STATUS AND WHISTLE-BLOWING}

While most organizational fraud are committed by senior management or from the accounting department, other employees in the organization may have knowledge of such heinous crime but will choose not to disclose. However, not all employees are adamant to exposing wrongdoing by their employer or superiors irrespective of their position in the organization. Example is the Enron debacle and countless others. Empirical evidence on job status and whistle-blowing are mixed. Bhatia (2012) established after investigating the effects of job title and minority status on perception of whistleblowing in the work place among 72 participants that whistle-blowing activities are more pronounced among lower staff especially when the relationship between superiors and lower staff are considered distant. Bhatia (2012) also found that high level staff are more likely to blow the whistle than their junior counterparts. Consistently, Mesmer-Magnus and Viswesvaran (2005) found in their meta-analysis study that young employees especially those on the lower organizational hierarchy are uncomfortable in reporting wrongdoings especially of their superiors. Lower employees feel that they lack the capacity to effect change in the organization and by blowing the whistle will rather jeopardize their prospects for progress. In contrast, Ahmad et al. (2012) revealed that senior officers possessed power and are very committed to their organizations' objectives hence will not compromise on any illegalities (MesmerMagnus and Viswesvaran 2005; Miceli \& Near, 1995). Senior officers' position and power make them responsible for achieving organization's strategic objectives hence their commitment in ensuring that their personal objectives aligns with organization's purpose. This prods them to point out any illegal activity because in achieving organizational objectives, they achieve their personal goal and vice versa. Based on the above literature the authors have hypotheses that:

$\mathrm{H}_{2}$ : There is positive significant effect between job status and whistle-blowing.

\subsection{RESEARCH DESIGN}

The research was based on the quantitative approach to analyze the effect between religiosity and job status on whistle-blowing. Specifically, cross-sectional survey research design was employed to determine the relationship between the independent variables (job status and religiosity) and the dependent variable (whistle-blowing). The services of micro finance institutions is on the ascendance with a high risk of fraud and mismanagement of funds and the study was to find out how employees dealt with illegal acts of their employers or supervisors. The research was based on deductive reasoning to ascertain the effect between religiosity, job status and whistle-blowing. The research design was therefore non-experimental.

\subsection{POPULATION, SAMPLE SIZE AND TECHNIQUE}

The target population for this research was all micro finance institutions in Ga-East District of the Greater Accra region of Ghana. The Ga-East district was selected because it happened to be one of the fast growing commercial district where numerous Micro Small and Medium Enterprises (MSMEs) reside, with equally thriving micro finance institutions due the financing gap between the formal banking industry and MSMEs in Ghana. Also given the increase in media reportage on the fraudulent activities of employees of some micro financial institutions in the district the researchers' choice of the district was justified. The convenience sampling technique was used to allow the researchers identify employees who were willing and able to answer the questionnaires.

A two stage sampling procedure was adopted in the study. The first stage involved the selection of micro finance institutions and the second stage involved the selection of participants. The total population size of micro finance institutions in the Ga East district was one hundred and fifty (150) companies out of which seventy five (75) companies were purposively sampled. The sampling criteria was based on the existence and operation of the company in the district for the past five years through available customers and company records. In all, 78 females (52\%) and 72 males (48\%) were interviewed taking into consideration the method for sample size calculation suggested by Green (1991) and Tabachnick and Fidell (1996), $N>50+8(p)$ where $p$ is the number of hypotheses being tested. 


\subsection{DATA COLLECTION PROCEDURE}

Data was collected using structured questionnaires which consisted of closed ended questions. The close-ended questions provided respondents with options to choose from a range of possible answers. Permission was obtained from the management of selected micro finance institutions and two days was used to solicit responses from the respondents. In each micro institution the selected respondents were educated on the concept of whistle-blowing after which management and employees were assured the confidentiality of the information given. The researchers then administered the questionnaires with envelopes to the respondents and were allowed thirty minutes for completion after which the questionnaires were collected in the sealed envelopes to protect respondents' privacy.

The instruments adopted for this study was the Santa Clara Strength of Religious Faith questionnaire (SCSORF) (1997) developed by Plante and Boccaccini (1997). The SCSORF is a 10 item scale with response in the Likert scale format of 'strongly disagree' to another extreme response of 'strongly agree' which assesses the strength of religious faith regardless of religious affiliation or denomination. The instrument adopted has been used by (Donahue \& Benson, 1995; Ellison 1991; Larson, Sherill, Lyons, Craigie, Thielman, Greenwold \& Larson 1992). Because the SCSORF does not contain references to any specific religious orientation, it was suitable for classes of peoples of all religious affiliations. The instrument has an internal validity or Cronbach alpha of .95 with a validity score ranging of 0.76 to 0.90 and a split half reliability score of .92. The scale allowed for categorization into two groups - high and low on religiosity.

Likewise the instrument used to collect the intent to whistle-blowing among employee included perception of intent, judgments of responsibility, feeling of anger and whistle-blowing decisions. Participants' perception of intent and feeling of anger was measured using a three-item scale based on work by Betancourt and Blair (1992) and Weiner (1995) with a reliability coefficient of 0.88 and 0.89 respectively. Judgment of responsibility was measured using a three-item scale by Struthers et al. (2001) and Weiner (1995) with a reliability coefficient of 0.89 . The whistle-blowing decisions of the participants was also measured using a three-item scale based on work by Miceli and Near $(1984,1985)$ with a reliability coefficient of 0.84 . The research used a 5 point Likert-type scale to rate questions that range from definite unwillingness to report (1) to definite willingness to report (5). The scale coupled with the demographic factors of employees gave the researchers an idea of what employees would consider about themselves and how it would affect their eventual decision to report a wrongdoing. The scales in the research were pre-tested to determine their suitability and reliability for the study. This was done by conducting a pilot study using a convenient sample of 30 employees from selected Micro Finance Institutions in another Metropolis other than the targeted sample. The results showed that, the reliability coefficients obtained for the scales were: Religiosity Scale $(\alpha=0.73)$ and Whistle-blowing Scale $(\alpha=0.40)$. The reliability value for the Whistle-blowing Scale for the pilot study is due to the sample size used for the pilot study as compared to the value of 0.75 after data was collected for a sample size of 150 .

\begin{tabular}{lrr} 
& Table 1: Reliability of instruments & Alpha \\
\hline Instrument & Number of Items & 0.88 \\
\hline Religiosity & 10 & 0.75 \\
Whistle-blowing & 9 & \\
\hline
\end{tabular}

\subsection{RESULTS AND DISCUSSIONS}

The results from table 2 below has exposed the relationship between religiosity and whistle-blowing using Pearson product-moment correlation coefficient.

\begin{tabular}{lccccr}
\hline \multicolumn{7}{c}{ Table 2: Pearson product-moment correlation between religiosity and whistle-blowing } \\
\hline Variable & $\mathrm{N}$ & Mean & SD & R & $p$ \\
\hline Religiosity & 150 & 4.47 & 0.54 & 0.201 & 0.007 \\
Whistle-blowing & 150 & 3.69 & 0.64 &
\end{tabular}


From the table the results indicates that the relationship between religiosity and whistle-blowing was significant at $0.007\left[r_{(148)}=0.201, p<0.05\right]$. The direction of correlation was positive but weak at 0.201 implying that the decision to blow the whistle to some extent is influence by religiosity but cannot be describe as significant. It therefore imply that the suggestion by $\mathrm{H}_{2}$ that there is positive significant effect between religiosity and whistle-blowing is not accepted as the relationship between the variables were very negligible. The results suggests that even though religiosity influence whistle blowing, a person's intention towards exposing unethical or corrupt activities of an employer or supervisor cannot entirely be dependent on religiosity. The outcome also implies that there are other motivating factors influencing whistle blowing and not necessarily the religious background of the employee. For example MesmerMagnus and Viswesvaran (2005), Near \& Miceli (1995) have suggested that the educational background of an employee is a determinant to whistle-blowing. They asserted that senior officers are often highly educated and are mostly in management positions and possess high levels of power to control organization's resources hence have higher propensity to blow the whistle than junior staff who are often not highly educated. Near \& Miceli (1995) is of the view that members of an organization who wield power are more easily able to report wrongdoing without suffering consequence and will have their allegations more seriously investigated. These sources of power are however available to higher level employees who are in management position and are often times highly educated. Employees in lower level position cannot boost of having official or unofficial control of an organization. Lower level educated employees, on the other hand, may not know the prevailing culture in an organization and maybe less committed to reporting or stopping wrong happening, Dworkin and Baucus (1998). Lower level educated employees may also not be familiar with appropriate channels for whistle-blowing.

The results is consistent with Martin (2013) who discovered in Malaysia that the intention to blow or actually blowing the whistle was dependent on the employees' values rather than the religious affiliation and orientation. Bhatia (2012) has describe values as conviction regarding what is important to a person in what to think, say or do. It is a principle or a quality considered worthwhile or desirable and validated by social approval. The results therefore implies that being notoriously religious without a fundamental belief system that helps in defining which is right, good and just cannot in itself influence whistleblowing. The result is also consistent with Othman and Hariri (2012) who also found insignificant relationship between religiosity and intentions to whistleblowing.

Other social-psychological literatures of prosocial behavior have also suggested that personality and situational variables are predictors of whistle blowing (Latanes and Darley, 1968, 1970). For example Tim, Bass, and Brown (1996) reported that individuals whose ethical philosophies can be labelled as principled or uncompromising than religious inclination were more likely to blow the whistle. Dozier and Miceli (1985) argue that observers' decision for whistle-blowing is affected by their personality traits, and the environment surrounding them. The outcome is however contrary to the theoretical assumption that employees who are religious have the ability to engaged in prosocial behaviors like whistleblowing than employee who are not religious (Einolf, 2011).

Also as part of the objectives Table 3 has showed the relationship between job status and whistle blowing. The hypothesis was tested using Pearson product-moment correlation coefficient.

\begin{tabular}{|c|c|c|c|c|c|}
\hline Variable & $\mathrm{N}$ & Mean & SD & $\mathrm{R}$ & $P$ \\
\hline Job Status & 150 & 1.31 & 0.46 & 0.031 & 0.354 \\
\hline Whistle-blowing & 150 & 3.69 & 0.64 & & \\
\hline
\end{tabular}

The results from the above shows that there is a weak positive relationship between job status and whistle-blowing which is not significant $\left[r_{(148)}=0.031, p>0.05\right]$. The outcome implies that even though job status of an employee may play a part in their decision to expose wrongdoing, the status of an employee alone cannot guarantee the decision to whistle blowing. The hypothesis that there will be a 
significant positive relationship between job status and whistle-blowing was therefore not supported. The result can be interpreted that the intention of an individual to come out to report any wrongdoing will depend on the job status of the individual but cannot be exclusively motivated by whether the employee is a senior or junior officers. The outcome of this study is consistent with several researches which found no association of individual performance, education and organizational position to whistleblowing (Goldman, 2001; Keenan, 2000; Miceli \& Near, 1988; Rothschild \& Miethe, 1999; Sims \& Keenan, 1998). The finding is inconsistent with Gokce (2013) who reported using a study group of 283 teachers in Turkey that whistle blowing intentions increases with the job status of employees. Consistently, Miceli \& Near (1984) also found after examining the 1980 U.S. Merit System Protection Board archival data that whistle blowing was positively related to individual job performance and that whistle blowers tended to be highly educated, high on the organizational ladder with better pay levels. Though the study did not consider the age of the employees when it comes to whistle-blowing (Dworkin \& Baucus 1998; Keenan, 2000; Lee, Heilmann \& Near 2004; Sims \& Keenan, 1998) have all concluded that older employees and people who have mostly worked in the organization for a long time are more likely to blow the whistle irrespective of the organizations hierarchy they belong and also younger employees are people who have not worked in an organization for a long time. It was also ascertained that both young and old employees can blow the whistle but in the case of younger employees the motivation to blow the whistle will depend on the relationship the younger employees have with their superiors.

\subsection{CONCLUSION AND POLICY IMPLICATION}

Whistle-blowing at workplace is a very important subject matter in any organization and should be encouraged across organizational settings irrespective of the job position and religiosity of an employee. The study has proven that though religiosity and job status can influence whistle-blowing, however in this study, the magnitude is negligible and perhaps other variables in concert with religiosity and job status may influence whistle-blowing activities in an organization. The study concludes that whistleblowing generally in the Ghanaian setting is yet to receive high prominence due to the general belief of lack of protection for persons who come out to expose wrongdoings and the general fear of harassment, victimization and loss of job by the whistle-blower.

Employees irrespective of the religious affiliation and job status must be encouraged to expose wrongdoing in the organization by instituting reward scheme by management and the protection of whistle-blower. Organizational members must be given orientation on whistle-blowing and be encourage to expose unethical behaviors and how to go about bringing it to management or public notice. Also, the incorporation of the whistle-blowers Act in the employment contract of employees in private organizations will make it obligatory for all workers to expose wrongdoings in organizations. This will make obligatory rather than voluntary for employees to report suspected or actual wrongdoings in private institutions. An assurance of not disclosing the whistle-blower will be of essence to the employee. The security of an employee in an organization should be guaranteed to ensure employees blow the whistle on wrongdoings whenever they chance upon one. Procedures and processes for reporting wrongdoing should be made flexible and easy to encourage employees from top level management through middle level management to lower level management to blow the whistle. Channels of communication within organizations must be reduced in hierarchy and practice of open door office could also be encouraged. Delayering of channels of communication could aid in making exposing wrongdoing a seamless process.

\section{REFERENCES}

Ahmad, S., Smith, G. M., \& Ismail, Z. (2012). Internal Whistle-Blowing Intentions: A Study of Demographic and Individual Factors. Journal of Modern Accounting and Auditing, 8(11), 1632-1645

Alford, C. F. (2003). Civil Society and its Discontents. The Good Society, 12(1), 11-16

Alford, C. F. (2007). Whistle-blower narratives: The experience of choice-less choice. Social Research: An 
International Quarterly of Social Sciences, 74(1), 223-248.

Allport, G. W. \& Ross, J. M. (1967). Personal religious orientation and prejudice. Journal of Personality and Social Psychology, 5, 447-457

Auriacombe, C. J. (2005). What happens when one blows the whistle? Recent South African cases. Sabinet online, 24(1), 85-100. Retrieved September 5, 2007, from the World Wide Web: http://www.subinet.co.za/abstracts/polit/polit_v24_n1_95_htm.

Betancourt, H. \& Blair, I. (1992). A cognition (attribution)-emotion model of violence in conflict situations. Personality \& Social Psychology Bulletin, 18(3), 343-350.

Bhatia, S. (2012). The Effects of Job Title and Minority Status on Perceptions of Whistle Blowing in the Workplace. University of Florida

Bowen, R. M., Call, A. C. \& Rajgopal, S. (2010). Whistleblowing: Target firm characteristics and economic consequences. The Accounting Review, 85(4), 1239-1271.

Brian, D. (2001). The Future of Organization Ethics in Africa. IBER 4(1). Retrieved September 5, 2007, from the World Wide Web: http://www.organization-ethics.org/newdetail.asp?news1d=20-27k

Brief, A. P. \& Motowidlo, S. J. (1986). Prosocial organizational behaviors. The Academy of Management Review, 11(4), 710-725.

Camerer, L. (1996). Ethics and the Professions: Blowing the Whistle on Crime. African security review, 5(6), 48-54

Chu, D. (2007). Religiosity and desistance from drug use. Criminal Justice and Behaviour, 34,661-679.

Dellaportas, S., Gibson, K., Alagiah, R., Hutchinson, M., Leung, P., \& Van Homrigh, D. (2005). Ethics, governance and accountability: A professional perspective. Australia: John Wiley \& Sons, Ltd.

Donahue M. J. \& Benson, P. L. (1995). Religion and the well-being of adolescent. Journal of Social Issue. $51,145-160$

Dozier, J. B. \& Miceli, M. P. (1985) "Potential predictors of whistle-blowing: A prosocialBehavior perspective". Academy of Management Review, 10, 823-836.

Dworkin, T. \& Baucus, M. S. (1998). "Internal vs. External Whistleblowers: A Comparison of Whistleblowing Process" Journal of Business Ethics (17). 1281-1298

Dyck, A., Adair, M., \& Zingales, L. (2010). Who blows the whistle on corporate fraud? Journal of Finance, 65, 2213-2254

Ellison C.G. (1991). Religious involvement and subjective well-being. Journal of Health and Social Behavior, 32, 80-99.

Fukuyama, M., \& Sevig, T. (1999). Integrating Spirituality into Multicultural Counselling. Sage Publications

Green, S. B. (1991). How many subjects does it take to do a regression analysis? Multivariate Behavioral Research, 26, 499-510

Greenberg, J. \& Baron, R.A (2003). Behaviour in Organizations (Eight edition). Prentice Hall: New Jersey

Johnson, R. A. (2003). Whistleblowing: When it works and why, Boulder, CO: Lynne Riener Publishers

Keenan, J.P. (2000). Blowing the whistle on less serious forms of fraud: A study of executives and managers. Employee Responsibilities and Rights Journal, 12(4), 85-94

Lacayo, R., \& Ripley, A. (2003). Persons of the year. Time, 38-39.

Larson, D.B., Sherill, K.A., Lyons, J.S., Craigie, F.C., Thielman, S.B., Greenwold. M.A., \& Larson, S.S. (1992). Association between dimensions of religious commitment and mental health. American Journal of Psychiatry, 149, 557-559.

Latane, B., \& Darley, J. (1969). "Bystander "Apathy", American Scientist, 57, 244-268.

Lee, J. Y., Heilmann, S.G., \& Near, J.P. (2004). Blowing the whistle on sexual harassment: Test of a model of predictors and outcomes. Human relations, 57(3), 297-322

Levin, S. \& Sidanius, J. (1999). "Social dominance and social identity in the United States and Israel: Ingroup favoritism or out-group derogation?" Political Psychology, 20, 99-126.

Martin E. D. (2013). Whistleblowing, religiosity, spirituality and integrity: Understanding the impact of Social Dominance Orientation and Environmental Context." Journal of Moral Organizational Psychology. 2 (3)

Mesmer-Magnus, J. R. \& Viswesvaran, C. (2005). Whistleblowing in organizations: Examination of correlates of whistleblowing intentions, actions, and retaliation. Journal of Business Ethics, 62(3), 277297. 
Miceli, M. P. \& Near, J. P. (1985). Characteristics of organizational climate and perceived wrongdoing associated with whistleblowing decisions. Personnel Psychology, 38(3), 525-544

Miceli, M., Near, J., Rehg, M. \& Scotter, J. (2008). Antecedents and Outcomes of Retaliation Against Whistleblowers: Gender Differences and Power Relationships. Organization Science, 19(2), 221-240.

Miceli, M.P, \& Near, J.P. (1988). Individual and Situational Correlates of Whistle-blowing. Personnel Psychology, 41(2), 267-281.

Morgan, (2004). Dealing with Religious Expression in the Workplace. Retrieved June 22, 2006 from www.law.com/jsp/article.jsp?id=900005466111

Near, J.P., \& Miceli, M.P. (1995). Effective whistle-blowing. The Academy of Management Review, 20(3), 679-708

Othman, R. \& Hariri, H. (2012). Conceptualizing religiosity influence on whistle-blowing intentions. British Journal of Economics, Finance and Management Sciences, 6(1), 62-92

Plante, T.G. \& Boccaccini, M. (1997). The Santa Clara Strength of Religious Faith Questionnaire. Pastoral Psychology, 45, 375-387

Pratto, F., Sidanius, J., Stallworth, L., \& Malle, B. (1994) "Social Dominance Orientation: A Personality Variable Predicting Social and Political Attitudes", Journal of Personality And Social Psychology, 67(4), 741-763.

Rossouw, D. (2002). Organization ethics in Africa. (2nd Ed.). Cape Town: Oxford University Press.

Sangweni, S. (2005). Parliamentary briefing on the 2005 Annual state of the Public service Report. Retrieved September 17, 2007, from the World Wide Web: http://www..pmg.org.za/briefings/briefings.php?id=185.

Schminke, M., Ambrose, M. L. \& Miles, J. A. (2003). The impact of gender and setting on perceptions of others' ethics. Sex Roles, 48(7/8), 361-375.

Sekeran, (2003). Research method for business: A skill building approach 4th edition, John Wiley \& Sons.

Sims, R. \& Keenan, J. (1998). "Predictors of External Whistle-blowing: Organizational and Interpersonal Variables". Journal of Business Ethics, 17(4), 411-42

Struthers, C.W., Miller, D. L., Boudens, C. J. \& Briggs, G. L. (2001). Effects of causal attributions on coworker interactions: A social motivation perspective. Basic and Applied Social Psychology, 23(3), 169181.

Stylianou, S. (2004). The role of religiosity on the Opposition to Drug Use. International Journal of Offender Therapy and Comparative Criminology, 48(4), 429-448

Tabachnick, B. G. \& Fidell, L.S. (1996).Using multivariate statistics (3rd Ed.). New York: Harper-Collins

Taylor, D. \& Pillemer, E. (2009). Using affect to understand employee turnover: a context-specific application of a theory of social exchange. Sociological Perspectives 52 (4), 481-504.

Tim Bass \& Brown (1996) Religiosity, ethical ideology, and intentions to report a peer's wrongdoing, Journal of Business Ethics, Vol 15, issue 11, pp 1161-1174

Treneman, A. (2004). 'Why Women do their Duty.' New Statesman, 17(7), 16.

Vadera, A. K., Vadera, R. V. \& Caza, B. B. (2009). Making sense of whistle-blowing antecedents: Learning from research on identity and ethics programs. Business Ethics Quarterly, 19, 553-586.

Vermeir, I., \& Van Kenhove, P. (2008). Gender differences in double standards. Journal of Business Ethics, 81(2), 281-295.

Whistleblowers Act of Ghana (Act 720), 2006 